FACTA UNIVERSITATIS

Series: Physical Education and Sport, Vol. 16, No 2, 2018, pp. 421 - 434

https://doi.org/10.22190/FUPES180707038P

Research article

\title{
SPORTS AND PHYSICAL ACTIVITY OF ELEMENTARY SCHOOL STUDENTS IN THEIR LEISURE TIME
}

\author{
UDC 796.364.23-057.847
}

\author{
Jelena Petrović ${ }^{1}$, Stojan Cenić ${ }^{2}$, Dragana Dimitrijević ${ }^{3}$ \\ ${ }^{1}$ Faculty of Philosophy, University of Niš, Serbia \\ ${ }^{2}$ Pedagogical Faculty in Vranje, University of Niš, Serbia \\ ${ }^{3}$ Center for Social Work in Leskovac, Serbia
}

\begin{abstract}
This paper aims to contribute to greater involvement of elementary school children in sports and physical activity in their leisure time. The paper first discusses the theoretic bases concerning leisure time activities structure; the patterns of family leisure, and the importance of sports and physical activities in both groups. Empirical research aims to gain insight into the current patterns of elementary school children' and their families' leisure time, and the frequency of sports and physical activity in their free time; also it examines the differences in orientation towards sports and physical activities between children from urban and rural surroundings and between two age groups (4th grade and 7th grade students), and finally it studies a correlation between family leisure patterns and students' own leisure choices. The research encompassed 189 students of urban and rural areas of the municipality of Leskovac. The students were examined by a 5-point Likert type scale and a questionnaire. Data processing was performed by the SPSS program. The main results led to the conclusions that: Families and schools have to play a significant role in raising awareness about the importance of physical activity and sports engagement within the student's' unstructured leisure time; there is a need to support rural schools in developing and sustaining school sports; and finally, family involvement in sports and recreational activities has to be supported in order to provide a model for students' greater involvement in sports and physical activities.
\end{abstract}

Key words: elementary school students, sports and physical activities, leisure time, family leisure

Received July 7, 2018 / Accepted October 27, 2018

Corresponding author: Jelena Petrović

University of Niš, Faculty of Philosophy, Ćirila i Metodija 2, 18000 Niš, Serbia

Phone: +381 18514312 •E-mail: jelena.petrovic@ filfak.ni.ac.rs 


\section{INTRODUCTION}

Leisure time is one of the most important aspects of children's lives and has great educational potential. With the right choice of activities, it can contribute to the positive development of a child's personality, and stimulate natural talents and development of a child's potential. On the other hand, if not well organized and prepared, but rather reduced to boredom and idleness, it can be the source of poor educational influences instead of having a useful and positive effect on the development of children. Contemporary authors (Mikanović \& Jevtić, 2015; Trnavac \& Đorđević, 2005) emphasize the twofold connection between leisure time and education that ensure the proper use of children's free time. The first one is education during leisure time, meaning that leisure time can be used for nurturing interests, building habits and developing personality; and the second one is education for leisure time meaning that education helps develop a proper relation toward free time. In this paper, we are interested in the second function. Its role is to teach children to value their free time and cleverly choose the activities they will commit their time to. It is a necessity of modern society to teach children how to make use of their free time because it is marked with increased leisure time and an abundance of opportunities for young people (Brankovic \& Mikanović, 2017). Out of this necessity the phenomena of leisure time culture and education were built, and they encompass many skills including self-planning, self-responsibility and critical self-evaluation. The importance of developing leisure time culture is emphasized by many authors (Branković \& Mikanović, 2017; Feldman \& Matjasko 2005; Fredricks \& Eccles, 2008; Mahoney \& Stattin, 2000; McHalle, Crouter, \& Tucher, 2001) who proved the connection between leisure time activities and the ability of adaptation and academic success or, on the other hand, depression and the emergence of risky behaviors. Children should be able to choose the activities that best suit their abilities and fulfill the basic functions of leisure time: rest, entertainment and personal development. This paper aims to contribute to involving sport and physical activity into education for leisure time and developing leisure time culture in elementary school children.

Many studies proved that physical activity and sports orientation are very important for the health, well-being and personal development of children. Those authors argue the importance of increasing the volume of physical activities in all age groups (Cvejić \& Ostojić, 2017), enriching the curricula of physical education which can bring many benefits, including development of positive psychological and social behavior patterns (Jovanović \& Zdravković, 2017); developing extracurricular activities (Cvejić \& Ostojić, 2017; Mitraković, Batez Simić Mikalački \& Janković, 2016) and supporting specific training in the context of some field of sport (Nikolić, Kocić, Berić, Cvetković, \& Krzalić, 2015). But when it comes to physical activity, fitness and health, it is leisure time that can also make a difference for children. Leisure time offers many opportunities for physical activities of children, and we need to educate children for making sports and physical activities an important part of their leisure time. On the other hand, sports and physical activities can contribute to fulfilling all of the three main functions of leisure time. Activities such as walking, swimming, sunbathing, excursions can be realized in the function of rest. For the purpose of entertainment or fun, release of boredom and the creation of a good mood, activities like dance, reading and social games could be organized. Personality development is achieved by universal development, and a contribution to physical and aesthetic qualities of the body, and by strengthening personality traits such as consistency, self-confidence, discipline, tolerance, and so on. 
Many studies analyzing leisure time patterns and structure, family leisure and health benefits emphasized the role of sport and physical activities in leisure time. Such was the research conducted by Brdar and Lončarić (2004) who studied the frequency of various activities that are usually realized in free time. The activities were not offered in advance, but the participants noted all the activities that they were practicing. On the basis of their answers a measuring instrument was subsequently made. The results pointed to nine factors, with sports as a very important one. The other activities included: socially desirable entertainment, socially undesirable entertainment, computer use, pets, time spent with brothers and sisters, reading and so on. Similar studies were carried out by Ilišin (1990, 2007), who analyzed various activities children practiced during their free time and recognized that they could be grouped and divided into patterns. Ilišin (2007: 189) named five cultural patterns of the leisure time of youths, namely: sports, family, activism, media and passive cultural patterns. This classification was an elaboration of an pre-existing one, defined by the same author (Ilišin, 1990: 299), which distinguished a rural, urban and elite pattern. The author concluded that a five-pattern definition was needed, because children's and young people's leisure time proved to be usually dominated by non-productive and passive activities or unorganized sports activities.

Some other researchers (Berc \& Blažeka Kokorić, 2012; Zabriskie \& McCormick, 2001) analyzed family leisure as the frame of children's leisure time and also found physical activity an important component of leisure time. Zabriskie \& McCormick (2001) explained the nature of family leisure through two distinct patterns of family leisure time: a core and balance family leisure pattern (the second of which is marked by higher organization and a more active approach). In this paper we also made a connection between students' and families' leisure time.

Other, also very significant studies (Eccles, Barber, Stone, \& Hunt, 2003; Eccles \& Barber, 1999; Fletcher, Nickerson, \& Wright, 2003) measured the correlations between some leisure activities and physical and psychological health benefits, school accomplishment and behavioral changes. Their findings mainly confirmed a positive correlation between highly structured leisure time activities and success in different realms of life. Unfortunately, some authors (Petrović \& Zotović, 2010) confirmed that the appearance and high frequency of many risky behaviors during leisure time led to failure in life or deterioration of health. The authors mentioned, and many others recognized the sports pattern as a very significant one, and more importantly, as the one that requires more attention because it has great potential for making children's leisure time more constructive and beneficial. Those researchers (Badrić, Prskalo, \& Šilić, 2011; Hoffert \& Sandberg, 2001; Mlinarević, 2004; Nippold, Duthie, \& Larsen, 2005; Posner \& Vandell, 1999; Stepanović, Videnović, \& Plut, 2009) also confirmed the importance of sports activities in leisure time. They further analyzed the role of different sports activities such as active sports trainings, recreational sports activities and attending sports manifestations. Physical activities in leisure time are also considered the natural continuation of physical education in schools, which, if successful "leads to more natural, creative and independent learning, which further leads to more motivation and desirability to start positive peer relationships" (Jovanović \& Zdravković, 2017: 196). Many of these findings emphasize the importance of popularization of sports activities that starts in schools and continues during the leisure time, in order to neutralize the negative effects of passive activities and excessive media consumption. 
The main aim of this paper is to analyze the orientation towards sports and physical activities in the leisure time of elementary school children and their families, in comparison to other activities the children choose for their leisure time. The data obtained will help us gain insight into the current patterns of elementary school children's leisure time, and point out to what degree sports and physical activities are represented in their free time. Also, the research will indicate the correlation between the leisure time of children and the family leisure time habits concerning sports and physical activities. The difference in orientation towards sports and physical activities between children from urban and rural surroundings and between two age groups was also measured. Bearing in mind that this aspect of free time has not been broadly empirically studied, we believe that the data obtained in this research will provide guidance for educational practice and all those involved in the upbringing of children and young people, especially in the field of sports and physical activity of children during their leisure time. Also, we hope this research to offer new hypotheses that can be the basis for some further research, and new theoretical frameworks of leisure time culture.

\section{The structure of leisure time activities}

Leisure is the time an individual can organize and use according to his own needs and desires while respecting the principle of freedom of choice as a basic principle of free time use. Children can spend their free time in different places, by exercising some of their free activities, at school, with their family, with friends, either independently or with the guidance of adults. The main features of leisure time are freedom from work obligations and freedom of choice, so it is often defined as "the time we are left with after we have completed all the work, school, family and social obligations, and we can use it according to our own interests, without external pressure and coercion, in the way that personally suits us most" (Trnavac \& Đorđević, 2005: 100). All activities that can be realized in free time can be divided on the basis of three criteria: 1) the type and level of engagement of young people, 2) the goal or functions that are achieved and 3) the degree of structure (Mohoney \& Stattin, 2000). Within the first criterion, passive and active activities can be distinguished. Activities relative to their goal and function are usually divided into those that encourage fun, enjoyment, development of interest, and personality (Pešić, Videnović, \& Plut, 2012: 155). In relation to the degree of structure, we differ structured and unstructured activities (Eccles \& Barber, 1999; Bartko \& Eccles, 2003; Mohoney \& Stattin, 2000). For the purposes of this paper we will guide the classification of activities according to the degree of structure, since all activities that children realize in their free time can be considered from the aspect of structure, which also applies to sports activities.

Structured activities are those organized by adults with the aim to contribute to the achievement of some social or behavioral goals. The examples of such activities are music lessons, sports clubs or scout clubs (Eccles \& Barber, 1999: 14; Fletcher et al., 2003: 641). They differ from relaxing and unstructured activities by a scheduled timetable, engagement rules, guidance and directing by one or more adult leaders, continuous development of skills with increasing challenges and complexity of activities. Data from different studies (Mohoney \& Stattin, 2010; Bartko \& Eccles, 2003; Eccles et al., 2003) showed that inclusion of children and young people in structured, prosocial activities contributes to the positive development of their personality, and that students 
who are involved in highly structured activities have generally better educational outcomes and more easily socialize compared to pupils not included in this group of activities.

Unstructured activities are relaxing and relatively spontaneous, taking place without some strict rules or guidance by adults. These activities include: video games, watching TV, going to the swimming pool, ping-pong, playing music, recreational sports such as playing basketball or football with friends, nights out, and so on (Mahoney \& Stattin, 2010). Within the unstructured, free activities, attending sport events can be included; watching movies; listening to music; playing games such as cards, puzzles, social games, playing with toys; outdoor games with friends; hiking, camping, running (Hofferth \& Sandberg, 2001). Although unstructured activities involve many active forms of leisure time, non-structured activities are dominated by passive forms of leisure and tend toward urban and media leisure time patterns.

The research (Pešić et al., 2012) realized in our area, showed that adolescents spend only about $5 \%$ of their free time on structured activities, while unstructured activities are significantly more represented. Bearing in mind that structured activities are very important for the positive development of children's personality and the prevention of behavioral disorders, these data imply the need for greater involvement of school and family in order to educate and motivate children and young people to engage in structured activities in their leisure time. Sport and recreational activities belong to a group of highly structured activities both in school and outside of it, and have significant potential for positive action on the development of children. They are realized at school within the framework of free activities and sports sections such as athletics, handball, basketball, football, volleyball. Although all free activities in the school belong to a group of extracurricular activities, they are structured and organized and therefore are important for children's leisure time (Janković \& Rodić, 2007; Trnavac \& Đorđević, 2005). The need for educational activities concerning unstructured activities is also evident. Families and schools have to play a significant role in raising awareness about the importance of physical activity and sports engagement within the unstructured leisure time.

\section{Family leisure time structure}

Family leisure is the time during which all family members carry out activities they have chosen together, thus contributing to the development of mutual trust, close relationships and family cohesion. Many authors (Berc \& Blažeka Kokorić, 2012; Zabriskie \& McCormick, 2001; 2003) emphasize that all activities realized during family leisure time can be grouped to form two patterns. Those are the core pattern and the balancing pattern and both of them are present in all families and play important functions. Engaging in core pattern helps family members to fulfill their need for gathering and communion through practicing familiar and customary family activities. Balancing activities provide the family with the opportunity to fulfill its need for change and diversity, acquire new experiences and develop adaptability. Some of the balancing activities are holidays, camping, visiting cultural and sports events, outdoor activities, water-based activities, adventure activities (Berc \& Blažeka Kokorić, 2012; Zabriskie \& McCormick, 2001). The balancing pattern is important for us because it involves greater commitment, physical engagement and support for sports activities. Activities within the 
core pattern are predominantly passive and non-productive activities, but their importance is reflected in maintaining the family's communion, and justifies their frequent realization. On the other hand, balancing activities require more detailed planning and organization, they take more time and usually are not realized often. Sport and physical activities can be realized within both patterns of family leisure, but families should put a special emphasis on sports which is more dominant in the balancing pattern and helps to develop an active and physically challenging attitude towards leisure time in children (Zabriskie \& McCormick, 2001).

\section{METHODS}

\section{The sample}

The sample comprised a total of 189 students of elementary schools in the area of the town of Leskovac. At the time the research was conducted, in the spring semester of 2017 , the students attended $4^{\text {th }}$ and $7^{\text {th }}$ grade of two elementary schools in the town of Leskovac: "Josif Kostić" and "Trajko Stamenković", and the elementary school "Radoje Domanović" in the village Manojlovce, that belongs to the same municipality.

\section{Variable sample}

As some previous researches (Bucknavage \& Worrell, 2005; Posner \& Vandall, 1999; Hofferth \& Sandberg, 2001) showed, statistically significant differences between the younger and older elementary school children concerning structured leisure time activity attendance (including sports and recreation), we decided to enter the age variable. The sample of participants was divided into two subgroups in terms of age. The first sub-group encompassed $934^{\text {th }}$ grade students $(\mathrm{N}=93)$, and the second sub-group encompassed $967^{\text {th }}$ grade students $(\mathrm{N}=96)$. For the needs of the second variable, the sample was also divided into two subgroups. The first sub-sample consisted of children from the urban area (the town schools, $\mathrm{N}=81)$. The second sub-sample consisted of children from the rural area $(\mathrm{N}=108$, the village school).

\section{Data processing}

The data was obtained by a specially constructed instrument containing a 5-point Likert type scale for measuring the frequency of unstructured activities in children's leisure time (10 items) and the frequency of different family leisure activities (11 items, representing two main patterns of family leisure) and a questionnaire containing 7 questions measuring children's involvement in structured activities. The categories on the scale ranged from never to a couple of times per week. Data processing was performed by SPSS 20. As part of the quantitative analysis, the basic descriptive statistics were calculated (Percent and Frequency, Arithmetic means (M), Standard deviation (SD)), level of statistical significance (p), t test, $\chi 2$ test, and Pearson's correlation coefficient. In order to ensure the reliability of the instrument, Cronbach's alpha test was applied. The alpha coefficient value was over $0,700(\alpha=769)$, indicating that the scale used was reliable and that data could be used for scientific purposes. 


\section{RESULTS}

\section{Unstructured physical activities}

Measuring the frequency of unstructured activities in students' leisure time showed how often students chose activities that did not require previous organization or patterns of repetition, including physical activities. Sport and physical activities were presented by two items: I spend my free time with my friends in walks and in open space, and My free time I spend with my friends playing football, basketball, hide and seek, badminton, driving bicycle or swimming. The other activities offered represented intellectual, artistic, literary or creative activities, and mainly passive activities encompassing playing video games, using social networks or watching TV.

Results showed that passive activities realized through media were the most frequent: $I$ use my free time to watch movies or listen to music $(\mathrm{M}=4.30)$ and I spend my free time using computer, phone or video games consoles $(\mathrm{M}=4.28)$. Sports and physical activities followed, with $55 \%$ of the students involved in sport-like activities (playing football, basketball, hide and seek, badminton, driving bicycle or swimming) a couple of times a week, and $20 \%$ of the students engaged in such activities once a week $(M=4.16)$. Students chose walks and open space activities a couple of times a week in $47 \%$ of the cases, and in $31 \%$ once a week $(M=4.13)$.

To test the differences in frequency of unstructured physical activities, in relation to the age of the students and the environment they come from (rural or urban settlements), the $t$ test was used. The statistical analysis showed that statistically significant difference between the age groups exists only regarding walks and free open space activities $(\mathrm{p}=0.021 ; \mathrm{M}=3.95$ and $M=4.30$ ) in the favor of older students. And, there was no statistically significant difference between the students living in rural or urban areas when choosing unstructured physical activities

\section{Structured physical activities}

Sports and physical activities were the most frequent choice of elementary school students when they chose among the offered structured activities. The instrument offered four of the most frequent groups of structured activities practiced as extracurricular activities in schools, and the three of the most frequent groups of structured activities outside the school. In both groups, organized sport activities were the most attended. The structured activity with the greatest involvement of students is represented with the statement: I train, or have I trained a sport in the previous year (swimming, football, basketball ...) where 137 students $(72.5 \%)$ responded positively and only $52(27.5 \%)$ were negative. The question regarding the structured activities organized by the school: I'm or I have been involved during the past year in the work of school sports club, came in second with $135(71.4 \%)$ students responding positively, while only $54(28.6 \%)$ responded that they did not participate in these activities. Sport clubs were chosen before all other school activities, including scientific and literary sections altogether (chosen by $54.5 \%$ of the students), culture and art clubs (chosen by $56.6 \%$ of the students), and preparation classes for competitions in schools (chosen by $47.6 \%$ of the students). Also, in individually organized structured free time activities, sports came before language schools and classes (chosen by $29.9 \%$ of the students) and music schools and classes (chosen by $15.3 \%$ of the students) 
Further analyses provided us with the information that there was no statistically significant difference between the students of different age groups. On the other hand, students in rural surroundings were shown to participate in school sports activities more often than students in urban surroundings. Here a statistically significant difference was confirmed, though it was not very distinct $(\chi 2=3.995 ; \mathrm{p}=0.046, \mathrm{p}<0.05)$. Also, the structured activities outside the school as sports trainings, although represented in both groups of students, are dominant among students in the urban environment. In this case, a statistically significant difference was more firmly confirmed $(\chi 2=6.447 ; \mathrm{p}=0.011, \mathrm{p}$ $<0.05)$. These data are presented in Table 1.

Table 1 Frequency of structured physical activities of elementary school students in relation to urban and rural surroundings

\begin{tabular}{|c|c|c|c|c|c|c|}
\hline & & Rural & Urban & $\chi^{2}$ & $\mathrm{df}$ & $\mathrm{p}$ \\
\hline \multirow{2}{*}{$\begin{array}{l}\text { I'm or I have been involved during the past } \\
\text { year in the work of school sports club. }\end{array}$} & Yes & 64 & 71 & \multirow{2}{*}{3,995} & \multirow{2}{*}{1} & \multirow{2}{*}{0,046} \\
\hline & No & 17 & 37 & & & \\
\hline \multirow{3}{*}{$\begin{array}{l}\text { I train, or have I trained a sport in previous } \\
\text { year (swimming, football, basketball ...). }\end{array}$} & Yes & 51 & 86 & \multirow{3}{*}{6,447} & \multirow{3}{*}{1} & \multirow{3}{*}{0,011} \\
\hline & No & 30 & 22 & & & \\
\hline & $\mathrm{No}$ & 24 & 28 & & & \\
\hline
\end{tabular}

\section{Physical activity in family leisure time}

As explained in the theoretical background of this paper, in analyzing family leisure time we were interested in the balancing pattern because it involved outdoor orientation, physical engagement and planning and organizing. We considered the balancing family pattern a precondition to creating a solid base for sports orientation in children. The most frequently represented activities of the balancing pattern in the families of students questioned were those involving some kind of sports and recreational activities: I take excursions and walks with my family $(\mathrm{M}=3.36)$; We spend time in family hobbies or recreational activities (cycling, badminton, swimming) ( $\mathrm{M}=3.26)$; With my family I go on trips (holidays, wintering, camping) $(\mathrm{M}=2.91)$; and I visit sports events with members of my family $(\mathrm{M}=2.63)$. The last one was considered appropriate because it showed whether interest for sports was nurtured inside the family. These activities were reported to happen in most families once a month. The data measuring the difference inside the variable concerning the age of the students is shown in the Table 2 .

Table 2 Frequency of balancing family leisure time activities in relation to the age of the students

\begin{tabular}{|c|c|c|c|c|c|c|c|}
\hline & School age & $\mathrm{N}$ & $\mathrm{M}$ & $\mathrm{Sd}$ & t-test & $\mathrm{df}$ & $\mathrm{p}$ \\
\hline $\begin{array}{l}\text { I take excursions and walks with } \\
\text { my family }\end{array}$ & $\begin{array}{l}4^{\text {th }} \text { grade } \\
7^{\text {th }} \text { grade }\end{array}$ & $\begin{array}{l}93 \\
96\end{array}$ & $\begin{array}{l}3,54 \\
3,19\end{array}$ & $\begin{array}{l}1,239 \\
1,049\end{array}$ & 2,094 & $\begin{array}{l}180, \\
107\end{array}$ & $\mathbf{0 , 0 3 8}$ \\
\hline $\begin{array}{l}\text { I visit sports events with } \\
\text { members of my family }\end{array}$ & $\begin{array}{l}4^{\text {th }} \text { grade } \\
7^{\text {th }} \text { grade }\end{array}$ & $\begin{array}{l}93 \\
96\end{array}$ & $\begin{array}{l}2,68 \\
2,59\end{array}$ & $\begin{array}{l}1,438 \\
1,396\end{array}$ & 0,406 & 187 & 0,685 \\
\hline $\begin{array}{l}\text { With my family I go on trips } \\
\text { (holidays, wintering, camping) }\end{array}$ & $\begin{array}{l}4^{\text {th }} \text { grade } \\
7^{\text {th }} \text { grade }\end{array}$ & $\begin{array}{l}93 \\
96\end{array}$ & 2,90 & $\begin{array}{l}1,360 \\
1,319\end{array}$ & $-0,069$ & 187 & 0,945 \\
\hline $\begin{array}{l}\text { We spend time in family hobbies } \\
\text { or recreational activities } \\
\text { (cycling, badminton, swimming) }\end{array}$ & $\begin{array}{l}4^{\text {th }} \text { grade } \\
7^{\text {th }} \text { grade }\end{array}$ & $\begin{array}{l}93 \\
96\end{array}$ & $\begin{array}{l}3,49 \\
3,03\end{array}$ & $\begin{array}{l}1,274 \\
1,425\end{array}$ & 2,354 & 187 & 0,020 \\
\hline
\end{tabular}


Table 2 shows us that a statistically significant difference can be noticed regarding the statements: I take excursions and walks with my family $(\mathrm{p}=0.038, \mathrm{p}<0.05)$, and We spend time in family hobbies or recreational activities (cycling, badminton, swimming) $(\mathrm{p}=0.020, \mathrm{p}<0.05)$. The parents of younger students are more involved in physical and outdoor activities and more often support sports and active orientation.

The data measuring the difference inside the variable concerning rural and urban surroundings were not represented here because they did not show a statistically significant difference. The only difference spotted was that the parents of students in rural surrounding spent slightly more time with their children involved in hobbies and recreational activities ( $\mathrm{p}=0,084, \mathrm{p}>0.05 ; \mathrm{M}=3.30$ and $\mathrm{M}=3.23$ ). We find it worth mentioning, although it did not prove as statistically significant, because we believe that sports and recreational activities in rural surroundings provide a good opportunity for quality family leisure time and that this aspect deserves greater attention.

\section{Correlation between physical activities in family leisure and physical activities in students' leisure time}

In order to understand the correlation between the structure of students' leisure time activities and family leisure structure, we used Pearson's correlation test. The correlation between the whole subscales is given in the Table 3 .

Table 3 The correlation between the structured and unstructured activities with core and basic family patterns

\begin{tabular}{lccc}
\hline & & $\begin{array}{c}\text { Core family leisure } \\
\text { pattern }\end{array}$ & $\begin{array}{c}\text { Balancing family } \\
\text { leisure pattern }\end{array}$ \\
\hline Unstructured & Pearson's correlation & 0,477 & 0,345 \\
activities & $\mathrm{p}$ & $\mathbf{0 , 0 0 0}$ & $\mathbf{0 , 0 0 0}$ \\
Structured & Pearson's correlation & 0,142 & 0,164 \\
activities & $\mathrm{p}$ & 0,052 & $\mathbf{0 , 0 2 4}$ \\
\hline
\end{tabular}

Table 3 shows that there is a correlation between unstructured students' activities and both family leisure patterns: basic (Pearson's correlation $=.477, \mathrm{p}=0.000$ ); and balancing (Pearson's correlation $=.345, \mathrm{p}=0.000)$ ). This correlation can be explained with the nature of unstructured activities: they are more flexible and give the students more space for involvement in both patterns of family leisure. Also, as expected, there was no correlation between structured activities and the core family leisure pattern (Pearson's correlation coefficient is $0.142, \mathrm{p}=$ $0.052 ; \mathrm{p}<0.05)$, because the core pattern is unstructured by itself and does not correlate with any kind of structure. Finally, Table 3 shows a positive correlation between the involvement of children in structured activities and the frequency of the activities belonging to the balancing family pattern (Pearson's correlation coefficient is $0.164, \mathrm{p}=0.024 ; \mathrm{p}<0.05$ ). We consider this result important because it indicates that the more time children spend with their families in balancing activities, which are usually planned and organized, the more they are prone to choosing organized and structured activities that take place outside the family.

After confirming the correlation between structured leisure time activities of students and balancing family leisure pattern, we proceeded to correlating separate items in order to find out the most contributing family activities. These results are shown in the Table 4. 
Table 4 The correlation between structured physical activities in students' free time and balancing activities in family leisure time

\begin{tabular}{lccccc}
\hline & & $\begin{array}{c}\text { I take } \\
\text { excursions } \\
\text { and walks } \\
\text { with my } \\
\text { family }\end{array}$ & $\begin{array}{c}\text { I visit sports } \\
\text { events with } \\
\text { members of } \\
\text { my family }\end{array}$ & $\begin{array}{c}\text { We spend time } \\
\text { in family } \\
\text { hobbies or } \\
\text { recreational } \\
\text { activities } \\
\text { (cycling, } \\
\text { badminton, } \\
\text { swimming) }\end{array}$ & $\begin{array}{c}\text { With my } \\
\text { family I go on } \\
\text { trips (holidays, } \\
\text { wintering, } \\
\text { camping) }\end{array}$ \\
\hline $\begin{array}{l}\text { I'm or I have been } \\
\text { involved during the } \\
\text { past year in the work } \\
\text { of school sports club. }\end{array}$ & $\begin{array}{c}\text { Pearson's } \\
\text { correlation }\end{array}$ & 0,025 & $0,160^{*}$ & $0,154^{*}$ & 0,019 \\
$\begin{array}{l}\text { I train, or have I } \\
\text { trained a sport in } \\
\text { previous year } \\
\text { (swimming, football, } \\
\text { basketball ...). }\end{array}$ & $\begin{array}{c}\text { Pearson's } \\
\text { correlation }\end{array}$ & 0,079 & $0,160^{*}$ & 0,117 & $0,216^{* *}$ \\
\hline & $\mathrm{p}$ & 0,279 & $\mathbf{0 , 0 2 8}$ & 0,109 & $\mathbf{0 , 0 2 8}$ \\
\hline
\end{tabular}

Regarding balancing family leisure activity I visit sports events with members of my family, a statistically significant positive correlation has been established in relation to both structured sports activities: I'm or have been involved in the past year in the work of school sports club. (Pearson's correlation coefficient is $0.160 ; \mathrm{p}=0.028, \mathrm{p}<0.05$ ) and I train, or have I trained a sport in previous year (swimming, football, basketball ...). (Pearson's correlation coefficient is $0.160 ; \mathrm{p}=0.028, \mathrm{p}<0.05)$. A positive correlation between these activities confirms that the sports-oriented style of family leisure time positively correlates sports and physical engagement of students in their own leisure time. The values of the calculated parameters showed a statistically significant positive correlation of the activity: We spend time in family hobbies or recreational activities (cycling, badminton, swimming) and student involvement in sportstructured activity: I'm or have been involved in the past year in the work of a school sports club. (Pearson's correlation coefficient is 0,$154 ; p=0,034, p<0,05$ ). The obtained data indicate that with the increase in the involvement of children in hobbies and recreational activities within their families, the inclusion of children in school sports activities also increases. Another balancing family leisure activity that we correlated because we found it supportive of the physical and sport-oriented students leisure is represented with the statement With my family I go on trips (holidays, wintering, camping). It correlated positively with the statement I train, or have I trained a sport in previous year (swimming, football, basketball ...). The students who travel with their parents and have regular summer and winter vacations, more regularly engage in sports.

\section{DISCUSSION}

This study showed encouraging results that despite dominant passive activities, a great number (more than 70\%) of school-children were engaged in unstructured physical activities at least once a week. These results confirm earlier studies that gave similar results showing 
passive activities as dominant, but sports and physically engaging activities as the second best choice of students (Badrić et al., 2011; Brdar \& Lončarić, 2004; Ilišin, 2007; Pešić et al., 2012). This result confirms the possibility of promoting physically engaging activities and creating healthier leisure time culture. We also obtained the expected result showing greater involvement in walks and free open space activities of older students. Naturally, students of a younger age are still supervised by the adults and less prone to idle walks, in contrast to older students who use this type of activity often for satisfying their social contacts. On the other hand, the students did not report any differences regarding unstructured sport activities, despite our expectations based on some previous studies within the same age range (Posner \& Vendall, 1999: 874), which showed that younger students were more prone to structured activities. A statistical analysis also showed that there is no statistically significant difference in choosing unstructured physical activities between the students living in rural and urban areas. This result was also expected because the realization of unstructured physical activities does not depend on environmental circumstances. This result is also encouraging because it implies that we can use educational influences in both surroundings and we do not need to adapt the methods or tools to specific surroundings.

In regard of structured sports and physical activities, the data show us the great engagement of students, and again confirm the good base for further promotion of sports, and the opportunity to contribute not only to the physical health, but also the mental health of children. Contrary to some previous studies (Bucknavage \& Worrell, 2005: 80; Posner \& Vandell, 1999: 872), there was no difference between the studied age groups, but the difference between rural and urban surroundings was confirmed as expected. The training sessions of different sports are usually more accessible in urban environments and naturally more students in urban surroundings are involved in them, while the students in rural schools turn to school clubs as a means of satisfying their need to practice some sport.

The assumption at the beginning of this paper that the balancing family pattern is very important for developing sports orientation in children, was also confirmed. Most of the balancing family activities in our research were sports oriented. These activities were reported to happen once a month, which can be considered a good result taking into consideration the data from other research (Berc \& Blažeka Kokorić, 2012) and the nature of the activities themselves. The result that the parents of younger students are more involved in physical and outdoor activities and more supportive of sports is, thus, promising because it ensures sports orientation from an earlier age. These findings are also similar to those obtained by some previous researchers (Yeung, Sandberg, Davis-Kean, \& Hofferts, 2001: 149).

Further study showed that the existence of a sports-oriented style of family leisure time inspires children to choose sports and physical activities in their own leisure time. Also, when the family tends to satisfy the needs and interests of their children through their shared hobbies and recreational activities, we can expect that children will be encouraged to satisfy their interests by engaging in similar activities available to them at school. Another correlation confirmed by our study showed that sports orientation on family vacations such as swimming, skiing, hiking or mountaineering, correlates with the students' interests and willingness to involve in sports. On the other hand, this correlation can be connected to the material status of families and the fact that families which can provide for frequent vocations, can also provide for sports equipment and club memberships. 


\section{CONCLUSION}

The general conclusion we can make from this research is that sports and physical activities are present and generally represented in the leisure time of children and their families to a satisfying degree. This makes a very solid base and a good ground for pedagogues and educators to further develop awareness of the importance of making sports and physical activities an even greater part of elementary school children's leisure time. Further, more specific results showed the points on which those educational interventions are more needed. In accordance with those results we can draw a couple of significant implications for practice.

The first relates to the unstructured leisure time activities of children. They are dominated by passive and non-productive activities, and the role of the pedagogues, elementary school teachers and parents should be the popularization of sports activities in leisure time, in order to neutralize the negative effects of passive activities and excessive media consumption. Children should be introduced to the different ways they could be physically active in their leisure time and the benefits of those activities on their health and general well-being. As the sample did not differentiate based on surroundings, we can conclude that such interventions are needed in both rural and urban surroundings, since in both surroundings children are equally prone to choosing video games and social networks over physical activities. On the other hand, in terms of age, we could see the greater involvement in physical activities of the younger children who are more supervised and more liable to educational influences. This can mean that the effort of the parents and educators should be to adjust their educational endeavors to the age of the children in order to maintain their influence up to an older age. This conclusion is also supported by results measuring family leisure time, which showed that parents of younger students were more involved in joint outdoor and physical activities.

The second implication relates to structured physical activities in students' leisure time. Those activities proved to be dominant in both age groups and in the general sample. The only difference was in relation to rural and urban surroundings showing us that in rural surroundings the students were involved in school organized structured sport activities, and in urban areas the students were mainly involved in structured sport activities outside of school. This difference is a direct consequence of the lesser availability of sports facilities, equipment, and so on, in rural surroundings, so the students turn to schools as the main source. The main implication of this conclusion for our educational system is that there is a need to support sport activities in rural schools, and/or to make sports more available to children in rural surroundings.

The third implication relates to the parental and family role in making sports and physical activities a routine of students' leisure time. The research showed that the more time children spend with their families in outdoor and recreational activities, which are usually planned and organized, the more they were willing to choose organized and structured activities in schools or in sport clubs. Also, in sport-oriented families, children more often choose sports and physical activities in their own leisure time. This leads to the conclusion that families should put special emphasis on sports and physically engaging activities and promote a positive attitude towards sports. This can be done by showing interest in sport activities and sport events and by actively becoming involved in recreational activities and so offering the children a model for sports and physical involvement during leisure time. 
This research also opened some topics for further research and analysis, especially the need to study possibilities and obstacles of developing school and family sport activities in rural surroundings, investigating the causes of passive orientation of children in their unstructured leisure activities and finding methods to overcome it, more closely researching gender and age differences in students choosing sports and physical activities in their leisure time, and so on.

\section{REFERENCES}

Badrić, M., Prskalo, I. \& Šilić, N. (2011). Razlike u strukturi slobodnog vremena između učenika urbanih i ruralni područja (Differences in leisure time structure between students in urban and rural areas). In: I. Prskalo, \& D. Novak (Eds.). Proceedings of the 6th FIEP Congres of Europe, Physical Education in the 21st Century-Pupils' Competencies, (pp. 58-64), Croatian Kinesiological Association.

Bartko, T., \& Eccles, J. (2003). Adolescent participation in structured and unstructured activities: A personoriented analysis. Journal of Youth and Adolescence, 32(4), 233-241.

Berc, G., \& Blažeka Kokorić, S. (2012). Slobodno vrijeme obitelji kao čimbenik obiteljske kohezivnosti i zadovoljstva obiteljskim životom (Family leisure as a factor of family cohesion and satisfaction with family life). Kriminologija i socijalna integracija, 20(2), 15-27. In Croatian

Branković, D., \& Mikanović, B. (2017). Vaspitanje i slobodno vrijeme (Education and leisure time). Banja Luka: Faculty of Philosophy, University of Banja Luka. In Serbian

Brdar, I., \& Lončarić, D. (2004). Suočavanje s akademskim stresom i aktivnosti u slobodnom vremenu učenika (Coping with academic stress in relation to leisure activities of elementary and high-school pupils). Društvena istraživanja, 6(74), 967-988. In Serbian

Bucknavage, B.L. \& Worrell, F.C. (2005). A study of academically talented students' participation in extracurricular activities. The Journal of Secondary Gifted Education, 16, 74-86.

Cvejić, D., \& Ostojić, S. (2017). Effects of the FITT program on physical activity and health-related fitness in primary school age children. Facta Universitatis, Series Physical Education and Sport, 15(3), 437 - 451

Eccles, J.S., \& Barber, B.L. (1999). Student council, volunteering, basketball or marching band: What kind of extracurricular involvement matters?. Journal of Adolescent Research, 14(1), 10-43. DOI: $10.1177 / 0743558499141003$

Eccles, J.S., Barber, B.L., Stone, M. \& Hunt, J. (2003). Extracurricular activities and adolescent development. Journal of Social Issues, 59(4), 865-889. DOI: 10.1046/j.0022-4537.2003.00095.x

Feldman, A.F., \& Matjasko, J.L. (2005). The role of school-based extracurricular activities in adolescent development: A comprehensive review and future directions. Review of Educational Research, 75, 159210. DOI: $10.3102 / 00346543075002159$

Fletcher, A.C., Nickerson, P.F. \& Wright, K.L. (2003). Structured leisure activities in middle childhood: Links to well-being. Journal of Community Psychology, 31, 641-659. DOI: 10.1002/jcop.10075

Fredricks, J., \& Eccles, J. S. (2008). Participation in extracurricular activities in the middle school years: Are there developmental benefits for African American and European American youth?. Journal of Youth and Adolescence, 37, 1029-1043. 10.1007/s10964-008-9309-4

Hofferth, S., \& Sandberg, J. (2001). How American children spend their time. Journal of Marriage and Family, 63, 295-308.

Ilišin, V. (1990). Slobodno vreme mladih seljaka (Free time of youth from rural areas). Sociologija sela, 28(109-110), 295-304. In Croatian

Ilišin, V. (2007). Slobodno vreme i interesi mladih (Youth leisure time and interests); In: V. Ilišin, \& F. Radin: Mladi: problem ili resurs (Youth: Problem or resource) (pp. 179-202). Zagreb: Institute for Social Research in Zagreb. In Croatian

Janković, P., \& Rodić, R. (2007). Školska pedagogija (School pedagogy). Sombor: Faculty of Education, University of Novi Sad. In Serbian

Jovanović M., \& Zdravković, D. (2017). Nonverbal communication and physical education classes in a social context. Facta Universitatis, Series Physical Education and Sport, 15(1), 195-206 DOI: 10.22190/FUPES1701195J.

Mahoney, J.L., \& Stattin, H. (2000). Leisure activities and adolescent antisocial behavior: The role of structure and social context. Journal of Adolescence, 23(2), 113-127.

McHale, M.S., Crouter, A. \& Tucher, C.J. (2001). Free-time activities in middle childhood. Child Development, 6, 1764 - 1778. DOI: $10.1111 / 1467-8624.00377$ 
Mikanović, B., \& Jevtić, B. (2015). Pedagogija-osnovna znanja o vaspitanju (Pedagogy: Basic knowledge about upbringing). Laktaši: Graformark. In Serbian

Mitraković D., Batez M., Simić M., Mikalački M. \& Janković, M. (2016). The significance of physical activity of young school children. Facta Universitatis, Series Physical Education and Sport, 14(3), 407-414 DOI: 10.22190/FUPES1603407M

Mlinarević, V. (2004). Stilovi slobodnog vremena srednjoškolaca Slavonije i Baranja (Free time styles of highschool students in Slavonia and Baranja). Pedagogijska istraživanja, 1(2), 241-256. In Croatian

Mohoney, J., \& Stattin, H. (2000). Leisure activities and adolescent antisocial behavior: The role of structure and social context. Journal of Adolescence, 23, 113-127.

Nikolić, D., Kocić, M., Berić, D., Cvetković, N., \& Krzalić, A. (2015). Motor abilities of children in urban and rural areas. Facta Universitatis, Series Physical Education and Sport, 13(1), 127-138

Nippold, M.A., Duthie, J.K., \& Larsen, J. (2005). Literacy as a leisure activity: Free-time preferences of older children and young adolescents. Language, Speech, and Hearing Services in Schools, 36(2), 93-102.

Pešić, J., Videnović, M., \& Plut, D. (2012). Slobodno vreme i pozitivan razvoj mladih: analiza budžeta vremena (Leisure and positive development of youth: The time use analyses). Psihološka istraživanja, 15(2), 153-168. In Serbian

Petrović, J., \& Zotović, M. (2010). Isti ili drugačiji: slobodno vreme mladih u Vojvodini i u svetu (Same or different: Leisure time of young people in Vojvodina and in the rest of the world). Zbornik Matice srpske za društvene nauke, 130, 73-88. In Serbian

Posner, J.K., \& Vandell, D.L. (1999). After-school activities and the development of low-income urban children: A longitudinal study. Developmental Psychology, 35(3), 868-879.

Stepanović, I., Videnović, M., \& Plut, D. (2009). Obrasci ponašanja mladih tokom slobodnog vremena (Youth spare time: Typical patterns of behavior). Sociologija, 51(3), 247-261. In Serbian

Trnavac, N., \& Đorđević, J. (2005). Pedagogija (Pedagogy). Belgrade: Naučna knjiga Komerc. In Serbian

Yeung, W.J., Sandberg, J.F., Davis-Kean, P.E. \& Hofferts, S.L. (2001). Children's time with fathers in intact families. Journal of Marriage and Family, 63, 136-154.

Zabriskie, R.B., \& McCormick, B.P. (2001). The influences of family leisure patterns on perceptions of family functioning. Family Relations, 50(3), 281-289.

Zabriskie, R.B., \& McCormick, B.P. (2003). Parent and child perspective of family leisure involment and satisfaction with family life. Journal of Leisure Research, 35(2), 163-189.

\section{ANGAŽOVANJE UČENIKA OSNOVNE ŠKOLE U SPORTSKIM I FIZIČKIM AKTIVONOSTIMA TOKOM SVOG SLOBODNOG VREMENA}

Ovaj rad ima za cilj da doprinese većem uključivanju učenika osnovne škole u sportske i fizičke aktivnosti u slobodno vreme. Rad se na početku bavi teorijskim osnovama za istraživanje analizirajući strukturu slobodnog vremena $i$ obrasce slobodnog vremena porodice, kao i značaj sportskih i fizičkih aktivnosti u oba slučaja. Empirijsko istraživanje ima za cilj sticanje uvida u trenutne obrasce provođenja slobodnog vremena osnovnoškolskih učenika i njihovih porodica, $i$ u učestalost sportskih $i$ fizičkih aktivnosti u njihovom slobodnom vremenu. Cilj je takođe utvrditi da li postoje razlike u orijentaciju ka sportskim i fizičim aktivnostima između dece iz ruralnih i urbanih sredna i između različitih uzrasnih grupa (učenika 4. i 7. razreda), kao i da li postoji korelacija između obrazaca slobodnog vremena učenika i slobodnog vremena porodice. Istraživanjem je obuhvaćeno 189 učenika osnovne škole iz urbanih i ruralnih oblasti opštine Leskovac. Instrument konstruisan za potrebe ovog istraživanja ispitivao je učenike petostepenom skalom likertovog tipa i upitnikom. Podaci su obrađeni pomoću SPSS programa. Najznačajniji rezultati doveli su do zaključka da: Porodica i škola moraju da igraju značajnu ulogu u podizanju svesti o značaju fizičkih i sportskih aktivnosti u nestruktuisanom slobodnom vremenu učenika: Postoji potreba za podrškom ruralnim školama u organizovanju i održavanju školskog sporta; i na kraju Da je potrebno podržati uključivanje porodice u sportske i rekreativne aktivnosti kako bi se stvorio model za veće angažovanje učenika u sportskim i fizičkim aktivnostima.

Ključne reči: učenici osnovne škole, sportske i fizičke aktivnosti, slobodno vreme, slobodno vreme porodice 